\title{
Effects of low dissolved oxygen on planula settlement, polyp growth and asexual reproduction of Aurelia aurita
}

\author{
Haruto IshiI*, TOSHIFUmi OHBa \& TAKeshi KoBAYASHI \\ Tokyo University of Marine Science and Technology, 4-5-7 Konan, Minato-ku, Tokyo, 108-8477, Japan
}

Received 8 February 2007; Accepted 11 October 2007

\begin{abstract}
Tokyo Bay is one of the most eutrophicated bays in Japan, and mass occurrences of scyphozoan jellyfish Aurelia aurita have often been observed with progress of eutrophication. In the coastal environment, the abundance of substrates suitable for $A$. aurita polyps are obviously increasing by reclamation. However, most suitable substrates for settling, except in the bottom-layer in the innermost part of Tokyo Bay, are occupied by other sessile organisms such as mussels, barnacles or ascidians. The bottom layer is characterized by low DO concentrations $\left(\leqq 2.0 \mathrm{ml} \mathrm{O}_{2} \mathrm{~L}^{-1}\right)$ that turn to hypoxia during summer, resulting in low recruitment and low growth of other sessile organisms. To elucidate the mechanism by which mass occurrence of jellyfish occurs, adaptative behavior to hypoxia in planula larvae and the polyp stage was experimentally studied. In the present study, planula settlement was promoted by a decrease in DO concentrations, and apparent growth of polyps and production of daughter polyps by asexual budding were also observed, even in the polyps cultured in hypoxic waters. Moreover $A$. aurita polyps cultured under hypoxic conditions began strobilation and ephyrae were liberated after the DO concentration levels were restored. It is suggested that the occurrence of hypoxic waters is rather favorable for the survival, growth and asexual reproduction of $A$. aurita polyps, and it can directly contribute to the consequent production of $A$. aurita ephyrae in the next spring within Tokyo Bay.
\end{abstract}

Key words: Aurelia aurita, hypoxia, jellyfish, polyp, Tokyo Bay

\section{Introduction}

The scyphozoan jellyfish Aurelia aurita (L., 1758) is found in many coastal waters (e.g. Möller 1980), and is a dominant predator in Tokyo Bay (Ishii \& Tanaka 2001). Tokyo Bay is one of the most eutrophicated bays in Japan, and mass occurrences of $A$. aurita have often been observed with the progress of eutrophication (Omori et al. 1995, Ishii 2001). Its life cycle includes an alternation between benthic polyp and planktonic medusa stages. The polyps asexually reproduce daughter polyps by budding and planktonic ephyrae by strobilation. It is important to know the environmental factors affecting the asexual reproduction process, since it is directly correlated to consequent mass occurrence events of medusae.

The bottom waters of eutrophicated bays experience low dissolved oxygen (DO) concentrations as a result of density stratification of the water column combined with microbial degradation of organic matter (Sanford et al. 1990), and hypoxia generally occurs during summer when density stratification of the water column limits vertical circulation of bottom waters (Turner et al. 1987). Usually hypoxia begins

*Corresponding author: Haruto Ishii; E-mail, ishii@kaiyodai.ac.jp at $2.0 \mathrm{mlO}_{2} \mathrm{~L}^{-1}$ of $\mathrm{DO}$ concentration and extends to $0 \mathrm{mlO}_{2} \mathrm{~L}^{-1}$, the point of anoxia (Diaz \& Rosenberg 1995). Hypoxic waters are stressful to fish and many other organisms, and their abundance, vertical migration and behavior can be significantly affected (Roman et al. 1993, Breitburg 1994, Breitburg et al. 1994, 1997, 1999, Miller et al. 2002). However, sometimes gelatinous species have an advantage in hypoxic waters, for example, the lobate ctenophore Mnemiopsis leidyi A. Agassiz, 1865 is more tolerant to hypoxia than its prey and other predators, and it is possible that ctenophores may increase prey consumption in hypoxic waters where they occur simultaneously (Decker et al. 2004). Concerning $A$. aurita, a recent study has shown that the medusae were more tolerable to low DO conditions ( $\leqq 4 \mathrm{mg} \mathrm{O}_{2} \mathrm{~L}^{-1}$; equal to $2.8 \mathrm{ml} \mathrm{O}_{2} \mathrm{~L}^{-1}$ ) than Spanish mackerel, and the number of fish larvae consumed by medusae increased with decreasing DO concentrations (Shoji et al. 2005). Thus the effects of low DO concentrations may dramatically impact trophic interactions in the water column (Breitburg et al. 1999, Keister et al. 2000, Decker et al. 2004, Grove \& Breitburg 2005).

The medusa stages of jellyfish appear to be tolerant to low DO concentrations, however, studies regarding the effect of hypoxia on the polyp stage are few, with the ex- 
ception of a study on Chrysaora quinquecirrha (Desor, 1848) polyps (Condon et al. 2001). Condon et al. (2001) suggested polyps were tolerant and can asexually reproduce even during prolonged exposure to hypoxic conditions. However, the response to low DO concentrations has not been studied for A. aurita, and the effects on planula settlement are entirely unknown. Sessile organisms such as polyps are usually exposed to severely low DO concentrations during summer. Actually in Tokyo Bay, it is known that low DO concentrations are stressful for most sessile and benthic organisms, and hypoxia differently affects the populations of these organisms (Furota 1991). The aim of the present study is to examine the effects of exposure to low DO concentrations on the planula settlement and growth and asexual reproduction of polyps in A. aurita.

\section{Materials and Methods}

\section{Field survey and sampling}

Sampling of Aurelia aurita medusae was conducted during daytime aboard the T.S. "Hiyodori" of the Tokyo University of Fisheries in the innermost part of Tokyo Bay once a month from June to December in 2000 and 2001 (Fig. 1). Female medusae with planulae were occasionally scooped from surface aggregations with a hand net $(10 \mathrm{~mm}$ mesh size) and kept in 20-L buckets with ambient seawater filtered through a $20 \mu \mathrm{m}$ mesh net. In some female medusae, planulae on the oral arms were immediately collected with a pipette and incubated in glass bottles $(900 \mathrm{ml})$ for polyp growth and asexual reproduction experiments. Surface water temperature was simultaneously measured at each medusa sampling station. At Station D, water sampling with a Niskin Water Sampler was conducted every $2 \mathrm{~m}$ between the surface and the bottom (ca. $10 \mathrm{~m}$ derth). The DO concentrations at each depth were determined by Winkler analysis in a land laboratory.

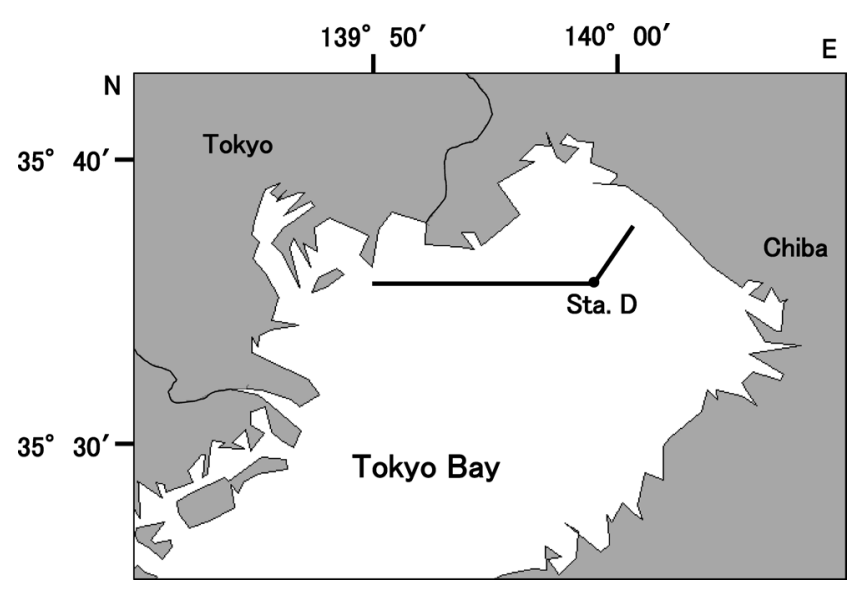

Fig. 1. Medusa sampling area in the innermost part of Tokyo Bay with survey line (solid line) and the water sampling station used in the DO analyses (Sta. D).

\section{Planula settlement experiment}

In the laboratory, each medusa was incubated in 20-1 buckets with ambient seawater filtered through a $20 \mu \mathrm{m}$ mesh net at $22^{\circ} \mathrm{C}$ (average water temperature in summerautumn season). For the planula settlement experiment, incubation seawater with medusae was frequently changed, and newly released planulae were immediately collected with a pipette from the incubation seawater by concentrating them with a $20 \mu \mathrm{m}$ mesh net. Planulae with a mean ratio of the diameter of the long axis to the short axis of $\geqq 2$ were used for experiments to eliminate undeveloped planulae (Ishii \& Takagi 2003).

Low DO concentrations $\left(0.2\right.$ and $\left.2.0 \mathrm{ml} \mathrm{O}_{2} \mathrm{~L}^{-1}\right)$ of incubation seawater were established and maintained by bubbling nitrogen gas into containers (1.8-1) filled with GF/C $\left(\right.$ Whatman $^{\circledR}$ ) filtered seawater. Small polystyrene balls covered the surface of each container. GF/C filtered seawater was used as a control $\left(4.5 \mathrm{ml} \mathrm{O}_{2} \mathrm{~L}^{-1}\right)$. Conditioned seawater was carefully introduced into experimental glass bottles $(70 \mathrm{ml})$. In addition to the experimental seawater, subsamples of the established seawater were collected to check DO concentrations. One hundred planulae were carefully transferred to each experimental glass bottle $(\mathrm{N}=9)$, and incubated under dark conditions. Water temperature was maintained at $22^{\circ} \mathrm{C}$. Each experimental glass bottle was sealed to prevent the diffusion of air into the bottles. After 0.25, $0.5,1,3,6,9,12,24,36$ and 48 hours, the numbers of settled and swimming planulae were counted using a dissection microscope. The settlement ratio of $A$. aurita planulae in each experimental bottle was determined as the ratio of the number of settled planulae to that of initially introduced planulae (100 inds).

\section{Polyp growth and asexual reproduction experiment}

In the laboratory, planulae in glass bottles $(900 \mathrm{ml})$ were transferred into glass bowls $(200 \mathrm{ml})$ filled with $1 \mu \mathrm{m}$ mesh-filtered seawater, and a floating acrylic plate $(5 \times 5$ $\mathrm{cm})$ for planula settlement. They were incubated under dark conditions. Water temperature was maintained at $22^{\circ} \mathrm{C}$. After 3 days, the feeding regime to the newly settled planulae was started. Artemia nauplii were supplied as food for A. aurita polyps every day. Early stages of polyps having an internal diameter of ca. $1 \mathrm{~mm}$ were used for the experiment, and unhealthy polyps were removed from the acrylic plate.

Target DO concentrations for polyp growth and asexual reproduction experiments were established according to the method described above. Polyps on the settling plate were introduced to the glass bottles $(100 \mathrm{ml})$ filled with seawater at each DO concentration. Each glass bottle was sealed to prevent the diffusion of air into the bottles, and they were incubated under dark conditions at $22^{\circ} \mathrm{C}$. For the growth and asexual reproduction experiments, 9-21 and 3 polyps, respectively, were used at each DO concentration.

All polyps were fed daily on cultured Artemia nauplii by 
a pipette in separate glass bowls $(200 \mathrm{ml})$ filled with seawater at their respective experimental DO concentrations, and simultaneously the internal diameter and number of asexually-reproduced daughter polyps were monitored using a dissection microscope. Swimming behavior of Artemia nauplii might be affected by low DO concentration, but apparent changes in food availability to the polyps were not observed among any of the experiments. Daughter polyps produced by asexual reproduction were removed in the growth experiments. Experiments were carried out for 18 days.

After the end of the above experiments, polyps were incubated under the same DO conditions and treatments as in the experiments. Due to high mortality in the $0.2 \mathrm{ml} \mathrm{O}_{2} \mathrm{~L}^{-1}$ treatment, those polyps were not used for the later strobilation experiment. Ten days after the above experiment concluded, water temperature was lowered to $12^{\circ} \mathrm{C}$ to induce strobilation, and some of the polyps from the settling plate incubated under DO concentrations of $2.0 \mathrm{ml} \mathrm{O}_{2} \mathrm{~L}^{-1}$ were transferred into the seawater control $\left(4.5 \mathrm{mlO}_{2} \mathrm{~L}^{-1}\right)$. For this experiment, some unhealthy and small polyps were also removed, and 24-30 polyps were used for each DO concentration experiment. Incubation was carried out according to the method described above. Daughter polyps produced by budding were immediately removed. Date of strobilation, number of strobilae, number of discs in strobila, date of ephyra liberation and number of newly liberated ephyrae were monitored. Liberated ephyrae were removed from the incubation seawater, and the diameters of the central disc of the ephyrae were determined. Experiments were carried out until the end of liberation of all ephyrae.

\section{Results}

The innermost part of Tokyo Bay was well mixed during all the months except from June to September, when stratification occured. During the sampling period in 2000-2001, maximum surface temperature was $30.6^{\circ} \mathrm{C}$ on 22 August, 2000, and the minimum was $13.4^{\circ} \mathrm{C}$ on 5 December, 2000 . The DO concentrations in the bottom layer in the innermost part of Tokyo Bay varied temporally ranging from $1.2 \mathrm{ml} \mathrm{O}_{2} \mathrm{~L}^{-1}$ (17\% air saturation) to near-saturation depending on the season (Fig. 2). The persistence of strongly stratified conditions and consequent low DO concentrations (hypoxia) in the bottom layer was apparent from June to September. Hypoxia in the bottom layer disappeared after October in both years.

Changes in the settlement ratio of Aurelia aurita planulae at the three different DO concentrations are shown in Fig. 3. During the incubation experiments, a few planulae ( $\leqq 2$ individuals in each bottle) were lost, however, dead planulae and polyps were not observed, even at the $0.2 \mathrm{mlO}_{2} \mathrm{~L}^{-1}$ concentration. Planula settlement was observed from the first observation in all treatments, but the degree of increase of the planula settlement ratio differed among the DO con-

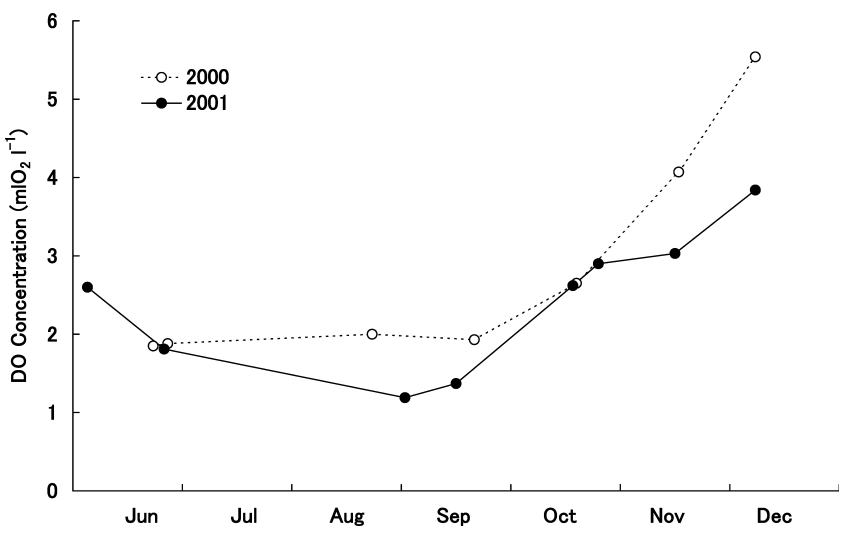

Fig. 2. Monthly changes of DO concentrations in the bottom layer ( $8 \mathrm{~m}$ depth) at Station D in Tokyo Bay from June to December in 2000 (broken line and open circle) and 2001 (solid line and closed circle).
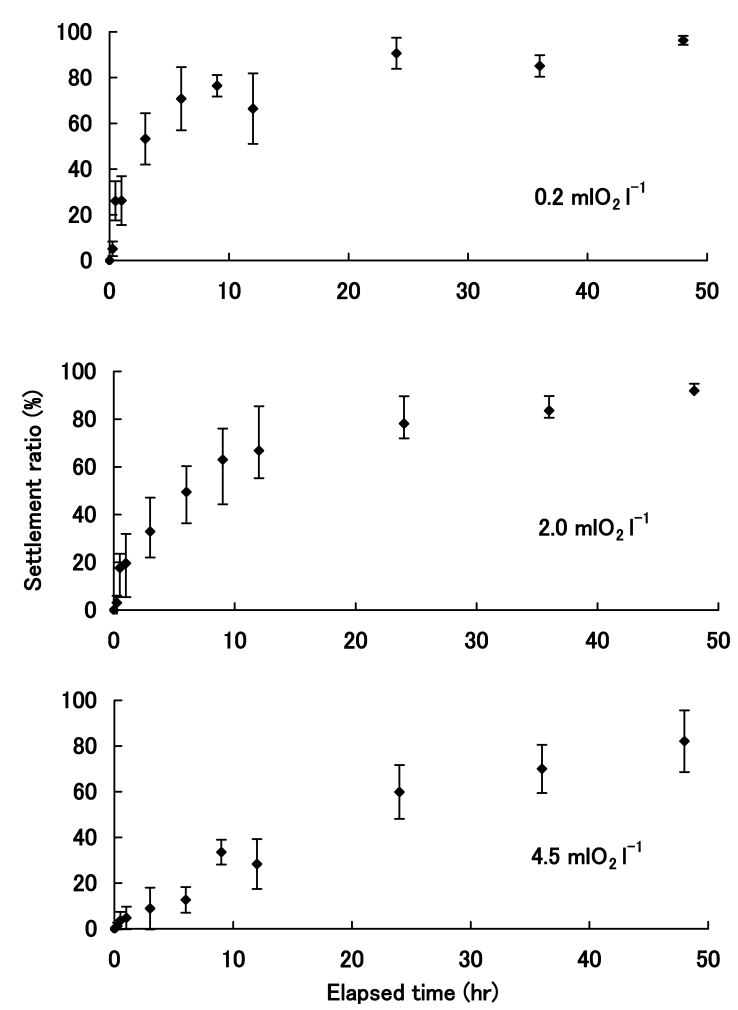

Fig. 3. Settlement ratio of Aurelia aurita planulae at three DO concentrations over 48 hours in a laboratory experiment.

centration treatments. Planula settlement was promoted by a decrease in DO concentration. Time required to attain $80 \%$ settlement was within 24 hours at the $0.2 \mathrm{ml} \mathrm{O}_{2} \mathrm{~L}^{-1}$ concentration, 36 hours at the $2.0 \mathrm{ml} \mathrm{O}_{2} \mathrm{~L}^{-1}$ concentration and 48 hours at the $4.5 \mathrm{ml} \mathrm{O}_{2} \mathrm{~L}^{-1}$ concentration.

Growth of polyps at each DO concentration is introduced in Fig. 4. At the $0.2 \mathrm{ml} \mathrm{O}_{2} \mathrm{~L}^{-1}$ concentration, polyp diameter decreased just after lowering the DO concentration. Half the total number of polyps died within 5 days, and all polyps were dead within 7 days. At the $2.0 \mathrm{ml} \mathrm{O}_{2} \mathrm{~L}^{-1}$ con- 
centration, the diameter of polyps increased despite the low DO concentration. All polyps survived until the end of the experiment, and the mean diameter attained was $2.3 \mathrm{~mm}$ after 18 days. At the $4.5 \mathrm{ml} \mathrm{O}_{2} \mathrm{~L}^{-1}$ concentration, all polyps continued to grow, and the mean diameter reached $2.4 \mathrm{~mm}$ after 18 days.

Cumulative numbers of daughter polyps, produced asexually by budding at each DO concentration treatment, are indicated in Figure 5. No daughter polyps were produced at

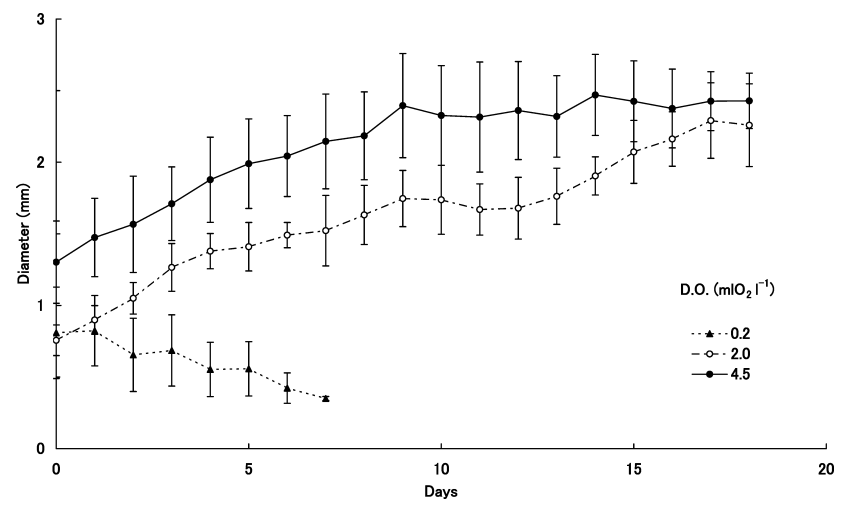

Fig. 4. Relationship between days elapsed from the beginning of the incubation experiment and the internal diameter of $A$. aurita polyps at three different DO concentrations. Data are plotted as means \pm S.D.

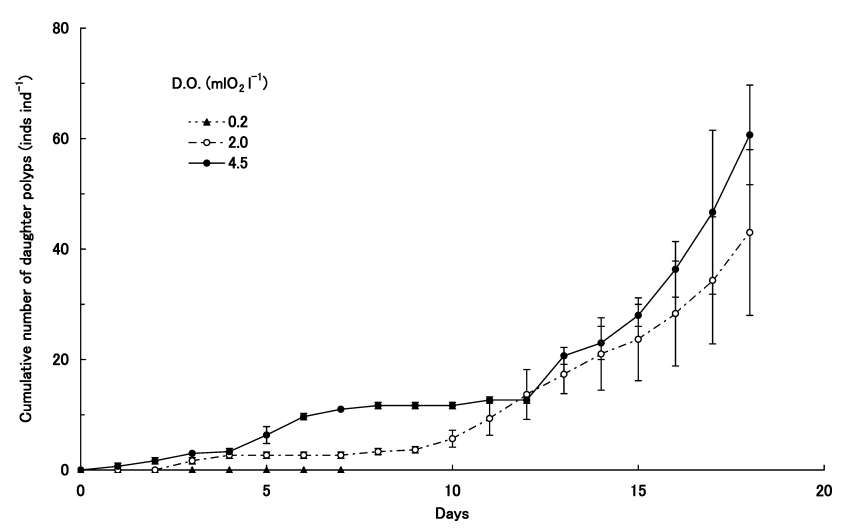

Fig. 5. Relationship between days elapsed from the beginning of the incubation experiment and the cumulative number of daughter polyps asexually reproduced by budding in $A$. aurita polyps at three different DO concentrations. Data are plotted as means \pm S.D. the $0.2 \mathrm{ml} \mathrm{O}_{2} \mathrm{~L}^{-1}$ concentration, since all polyps died within 7 days. At the other two DO concentrations, many daughter polyps were produced, and the cumulative number of polyps reached 43 and 61 individuals, respectively, at the 2.0 and $4.5 \mathrm{ml} \mathrm{O}_{2} \mathrm{~L}^{-1}$ concentrations.

Apparent growth and asexual reproduction by budding was observed even in the polyps incubated at $2.0 \mathrm{ml} \mathrm{O}_{2} \mathrm{~L}^{-1}$ concentration. However, strobilation was not observed in these polyps (Table 1). After DO concentration levels were raised from 2.0 to $4.5 \mathrm{ml} \mathrm{O}_{2} \mathrm{~L}^{-1}$, strobilation and ephyra liberation were observed. Strobilae were first observed 38 and 43 days after lowering the water temperature in polyps previously incubated at 2.0 and $4.5 \mathrm{ml} \mathrm{O}_{2} \mathrm{~L}^{-1}$ concentrations. By the end of the experiments, the ratio of strobilae to all polyps increased to more than $40 \%$ for both DO treatments. No significant differences in days until strobilation, strobilation ratio, strobilation running days, number of discs produced or liberated ephyrae diameter, were observed between the polyps previously incubated at 2.0 and $4.5 \mathrm{ml} \mathrm{O}_{2} \mathrm{~L}^{-1}$ concentrations.

\section{Discussion}

In hypereutrophicated bays like Tokyo Bay, it is well known that benthic hypoxic waters occur during summer, and that they are stressful for most sessile and benthic organisms (Furota 1991). Most of the benthic and sessile organisms disappear from the bottom layer, and this layer becomes nearly azoic from summer to early autumn in Tokyo Bay. Adverse effects of hypoxia to the survival of mantis shrimp Oratosquilla oratoria (De Haan 1844) juveniles in Tokyo Bay has been described (Kodama et al. 2006). However, some species can tolerate hypoxic conditions. The polychaete Paraprionospio pinnata (Ehlers 1901) can survive even in the almost anoxic conditions at the muddy bottom in Tokyo Bay (Furota 1991). Ritter \& Montagna (1999) also observed that polychates and oligochaetes tolerated hypoxic conditions better than other benthic species in a Texas Bay. In other words, hypoxia affects the population prosperity of living organisms differently according to taxon (Breitburg et al. 1999, Keister et al. 2000, Decker et al. 2004, Grove \& Breitburg 2005).

Few previous studies have examined the effects of hypoxia on benthic scyphozoan polyps. Condon et al. (2001) documented the high survivorship of Chrysaora

Table 1. Relationships between DO concentrations and reproduction of discs in strobila (means \pm SD).

\begin{tabular}{|c|c|c|c|c|c|c|c|c|}
\hline \multirow{2}{*}{$\begin{array}{l}\text { Changes of D.O. } \\
\text { concentration }\left(\mathrm{ml} \mathrm{O}_{2} \mathrm{~L}^{-1}\right)\end{array}$} & \multirow[b]{2}{*}{$\mathrm{N}$} & \multicolumn{4}{|c|}{ Strobilation } & \multicolumn{3}{|c|}{ Ephyrae } \\
\hline & & $\begin{array}{c}\text { Days until } \\
\text { starting dates }\end{array}$ & Ratio (\%) & Duration & $\begin{array}{l}\text { Mean number } \\
\text { of discs }\end{array}$ & $\mathrm{N}$ & $\begin{array}{l}\text { Diameter } \\
(\mathrm{mm})\end{array}$ & $\mathrm{N}$ \\
\hline $2.0 \rightarrow 2.0$ & 30 & - & - & - & - & - & - & 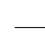 \\
\hline $2.0 \rightarrow 4.5$ & 24 & $37.6 \pm 6.0$ & 45.8 & $22.8 \pm 4.4$ & $7.1 \pm 1.8$ & 11 & $2.1 \pm 0.2$ & 26 \\
\hline $4.5 \rightarrow 4.5$ & 30 & $42.9 \pm 7.2$ & 43.3 & $17.1 \pm 2.7$ & $6.1 \pm 1.2$ & 13 & $1.9 \pm 0.2$ & 34 \\
\hline
\end{tabular}


quinquecirrha polyps even at low DO concentrations (1.5 $\mathrm{mg} \mathrm{O}_{2} \mathrm{~L}^{-1}$; equal to $1.05 \mathrm{ml} \mathrm{O}_{2} \mathrm{~L}^{-1}$ ). They suggested polyps could asexually reproduce even during prolonged exposure to hypoxic conditions. Our results also indicate that $A$. aurita polyps can survive and asexually reproduce daughter polyps under hypoxic conditions. We were unable to observe strobilation and ephyra liberation under prolonged low DO concentrations, but strobilation and ephyra liberation was observed if DO concentrations were restored to higher levels. In Tokyo Bay, bottom hypoxic water disappears after October. It is suggested that polyps surviving in the hypoxic bottom layers will continue to asexually reproduce daughter polyps during summer and early autumn, and as the bottom DO concentrations increase, strobilation and ephyra liberation occurs during winter.

We observed that planula settlement was enhanced by hypoxic conditions, and that these same conditions were not good for the survival of planulae. The respiration rate of planulae in Aurelia aurita has been reported as $3.5 \mu 1 \mathrm{O}_{2} \mathrm{mg}$ $\mathrm{DW}^{-1} \mathrm{hr}^{-1}$ at $19.6-21.5^{\circ} \mathrm{C}$ (Schneider \& Weisse 1985). A preliminary experiment by the senior author (H. I.) showed that the respiration rate of newly settled $A$. aurita polyps was $1.05 \mu 1 \mathrm{O}_{2} \mathrm{mg} \mathrm{DW}^{-1} \mathrm{hr}^{-1}$ at $22^{\circ} \mathrm{C}$. It would be impossible for planulae to remain in hypoxic waters for long, since they cannot ingest any prey but lose their carbon by respiration due to continuous swimming. We assume that metabolic demand should decrease after settlement, since the weight specific respiration rate of polyps is lower than that of planulae (Schneider \& Weisse 1985). An increase in the planula settlement ratio would be one adaptative behaviors invaluable for survival in hypoxic conditions.

Regarding the physiological adaptation system of organisms living at low DO concentrations, Childress \& Seibel (1998) proposed some possibilities, including the development of effective mechanisms of respiration, reduction of metabolic demand, and utilization of anaerobic metabolism. A suitable explanation for growth under hypoxic conditions could be that polyps also alternate between aerobic and anaerobic metabolism during prolonged exposure to hypoxic conditions, like some gelatinous medusae (Thuesen \& Childress 1994, Childress \& Seibel 1998). Recently the adaptation system of jellyfish to hypoxia through oxyregulation has been studied (Rutherford \& Thuesen 2005, Thuesen et al. 2005). Thuesen et al. (2005) demonstrated with Aurelia labiata that gelatinous medusae utilize intragel oxygen to meet their metabolic needs, and the gel can also be used as an oxygen reservoir for medusae living in hypoxic waters.

Watanabe \& Ishii (2001) observed the succession of A. aurita polyps on a settling plate moored from piers in the innermost part of Tokyo Bay, and the invasion and growth of other sessile organisms such as the mussel Mytilus galloprovincialis Lamarck, 1819. It is noted that these organisms completely covered the surface of the settling plates on both sides as a mussel bed from February to September. In nature, most substrates suitable for settlement in the inner- most part of Tokyo Bay are occupied by other sessile organisms such as mussels, barnacles or ascidians (Kajihara 1977, Furuse \& Furota 1985). This observation means that A. aurita polyps are exposed to keen competition for space with other sessile organisms, especially during summer when most planulae are released from female medusae. If the settlement of planulae is prevented by the presence of other organisms as observed in Watanabe \& Ishii (2001), the consequent production of ephyrae could be low in the following spring. However, if invasion by other sessile organisms were to be prevented, the abundance of $A$. aurita polyps would actually increase by asexual budding during summer. In the innermost part of Tokyo Bay, substrates exposed to hypoxic bottom-layer waters during summer would be one good place for A. aurita polyp settlement. Because the hypoxic bottom-layer is characterized by low recruitment and growth of other sessile organisms such as M. galloprovincialis (Furota 1991), some substrates suitable for planula settlement and polyp growth and reproduction become available as a result.

The present study showed the high tolerance and continuous growth and asexual reproduction by budding of $\mathrm{A}$. $a u$ rita polyps in waters with low DO concentrations. Condon et al. (2001) observed that the proportion of polyps undergoing strobilation decreased with decreasing DO concentrations. Strobilation was not observed in polyps incubated under constant low DO concentrations in the present study, however, it is remarkable that $A$. aurita polyps began strobilation and ephyra liberation after the disappearance of hypoxic conditions. These findings suggest that the occurrence of hypoxic waters is important for survival, growth and asexual reproduction, since few competitors can survive such conditions. It is assumed that dense colonies of $A$. aurita polyps in the bottom hypoxic layer causes consequent production of A. aurita ephyrae in the next spring and mass occurrence of jellyfish in the next summer within Tokyo Bay.

Besides of the obvious increase in suitable habitats for A. aurita polyps that is accompanied with progress in reclamation and construction along coastal regions, various artificial factors contribute to the prosperity of $A$. aurita population in Tokyo Bay (Ishii 2001). For example, the strobilation ratio of polyps and the number of liberated ephyrae increased with decreasing light conditions due to eutrophication (Custance 1964, Ishii \& Shioi 2003). Many estuaries and bays, such as Tokyo Bay, are characterized by seasonal hypoxia or anoxia induced by eutrophication. The senior author (H. I.) found polyp colonies of $A$. aurita by SCUBA diving only in the bottom hypoxic layers $\left(<3 \mathrm{mg} \mathrm{O}_{2} \mathrm{~L}^{-1}\right.$; equal to $2.1 \mathrm{ml} \mathrm{O}_{2} \mathrm{~L}^{-1}$ ) in Tokyo Bay, where most of the species that could compete with $A$. aurita polyps for space were absent or dormant from summer to early autumn. In terms of polyp survival and production under the hypoxic conditions, mass occurrences of jellyfish in many estuaries and bays could be caused by the progress of bottom hypoxia accompanied with eutrophication. In order to predict 
the overall effect of hypoxia on the jellyfish population, more information is needed on the habitat requirements and environmental conditions necessary to sustain polyp colonies of A. aurita. These will also help to elucidate how jellyfish could become dominant over fishes in regions affected by severe hypoxia, and how energy pathways are altered in these ecosystems (Breitburg et al. 1999, Sommer et al. 2002).

\section{Acknowledgments}

We are grateful to Prof. M. Omori for his advice and constructive comments on this study. Helpful assistance was given by the captain and crew of the T. S. 'Hiyodori' and members of the Ecology Laboratory of Tokyo University of Marine Science and Technology. This paper was first presented at the Topic Session on 'The human dimension of jellyfish blooms' convened at the PICES Fifteenth Annual Meeting in Yokohama, Japan, October 2006. This research was partially supported by research grants from the Ministry of Education and Science of Japan (No. 13660179). We greatly appreciate the critical comments of two anonymous reviewers.

\section{References}

Breitburg DL (1994) Behavioral responses of fish larvae to low oxygen risk in a stratified water column. Mar Biol 120: 615-625.

Breitburg DL, Steinburg N, DeBeau S, Cooksey C, Houde ED (1994) Effects of low oxygen on predation on estuarine fish larvae. Mar Ecol Prog Ser 104: 235-246.

Breitburg DL, Loher T, Pacey CA, Gerstein A (1997) Varying effects of low dissolved oxygen on trophic interactions in an estuarine food web. Ecol Monogr 67: 489-507.

Breitburg DL, Rose KA, Cowan Jr JH (1999) Linking water quality to larval survival: predation mortality of fish larvae in an oxygen-stratified water column. Mar Ecol Prog Ser 178: 39-54.

Childress JJ, Seibel BA (1998) Life at stable low oxygen levels: adaptations of animals to oceanic oxygen minimum layers. J Exp Biol 201: 1223-1232.

Condon RH, Decker MB, Purcell JE (2001) Effects of low dissolved oxygen on survival and asexual reproduction of scyphozoan polyps (Chrysaora quinquecirrha). Hydrobiologia 451: 89-95.

Custance DRN (1964) Light as an inhibitor of strobilation in $\mathrm{Au}$ relia aurita. Nature 204: 1219-1220.

Decker MB, Breitburg DL, Purcell JE (2004) Effects of low dissolved oxygen on zooplankton predation by the ctenophore Mnemiopsis leidyi. Mar Ecol Prog Ser 280: 163-172.

Diaz RJ, Rosenberg R (1995) Marine benthic hypoxia: a review of its ecological effects and the behavioural responses of benthic macrofauna. Oceanogr Mar Biol Annu Rev 33: 245-303.

Furota T (1991) Survival and population maintenance of macrobenthic animals in inner Tokyo Bay. Bull Coast Oceanogr 28: 160-169.

Furuse K, Furota T (1985). An ecological study on the distribution of intertidal sessile animals in inner Tokyo Bay. Mar Fouling 5: $1-6$.

Grove M, Breitburg DL (2005) Growth and reproduction of gelatinous zooplankton exposed to low dissolved oxygen. Mar Ecol Prog Ser 301: 185-198.

Ishii H (2001) The influence of environmental changes upon the coastal plankton ecosystems, with special reference to mass occurrence of jellyfish. Bull Plankton Soc Jpn 48: 55-61.

Ishii H, Shioi H (2003) The effects of environmental light condition on strobilation in Aurelia aurita polyps. Sessile Organisms 20: $51-54$.

Ishii H, Takagi A (2003) Development time of planula larvae on the oral arms of the scyphomedusa Aurelia aurita. J Plankton Res 25: 1447-1450.

Ishii H, Tanaka F (2001) Food and feeding of Aurelia aurita in Tokyo Bay with an analysis of stomach contents and a measurement of digestion times. Hydrobiologia 451: 311-320.

Kajihara T (1977) Marine attaching animals in Tokyo Bay. Mar Sci Monthly 9: 346-350.

Keister JE, Houde ED, Breitburg DL (2000) Effects of bottomlayer hypoxia on abundances and depth distributions of organisms in Patuxent River, Chesapeake Bay. Mar Ecol Prog Ser 205: 43-59.

Kodama K, Horiguchi T, Kume G, Nagayama S, Shimizu T, Shiraishi H, Morita M, Shimizu M (2006) Effects of hypoxia on early life history of the stomatopod Oratosquilla oratoria in a coastal sea. Mar Ecol Prog Ser 324: 197-206.

Miller DC, Poucher SL, Coiro L (2002) Determination of lethal dissolved oxygen levels for selected marine and estuarine fishes, crustaceans, and a bivalve. Mar Biol 140: 287-296.

Möller H (1980) Population dynamics of Aurelia aurita medusae in Kiel Bight, Germany (FRG). Mar Biol 60: 123-128.

Omori M, Ishii H, Fujinaga A (1995) Life history strategy of Aurelia aurita (Cnidaria, Scyphomedusae) and its impact on the zooplankton community of Tokyo Bay. ICES J Mar Sci 52: 597-603.

Ritter C, Montagna PA (1999) Seasonal hypoxia and models of benthic response in a Texas Bay. Estuaries 22: 7-20.

Roman MR, Gauzens AL, Rhinehart WK, White JR (1993) Effects of low oxygen waters on Chesapeake Bay zooplankton. Limnol Oceanogr 38: 1603-1614.

Rutherford Jr LD, Thuesen EV (2005) Metabolic performance and survival of medusae in estuarine hypoxia. Mar Ecol Prog Ser 294: 189-200.

Sanford LP, Sellner KG, Breitburg DL (1990) Covariability of dissolved oxygen with physical processes in the summertime Chesapeake Bay. J Mar Res 48: 567-590.

Schneider G, Weisse T (1985) Metabolism measurements of Aurelia aurita planulae larvae, and calculation of maximal survival period of the free swimming stage. Helgoländer Meeresunters 39: 43-47.

Shoji J, Masuda R, Yamashita Y, Tanaka M (2005) Effects of low dissolved oxygen concentrations on behavior and predation rates on red sea bream Pagrus major larvae by the jellyfish Aurelia aurita and by juvenile Spanish mackerel Scomberomorus niphonius. Mar Biol 147: 863-868.

Sommer U, Stibor H, Katechakis A, Sommer F, Hansen T (2002) Pelagic food web configurations at different levels of nutrient 
richness and their implications for the ratio fish production: primary production. Hydrobiologia 484: 11-20.

Thuesen EV, Childress JJ (1994) Oxygen consumption rates and metabolic enzyme activities of oceanic California medusae in relation to body size and habitat depth. Biol Bull 187: 84-98.

Thuesen EV, Rutherford Jr LD, Brommer PL, Garrison K, Gutowska MA, Towanda T (2005) Intragel oxygen promotes hypoxia tolerance of scyphomedusae. J Exp Biol: 208:
2475-2482.

Turner RE, Shroeder WE, Wiseman Jr WJ (1987) The role of stratification in the deoxygenation of Mobile Bay and adjacent shelf bottom waters. Estuaries 10: 13-20.

Watanabe T, Ishii H (2001) In situ estimation of ephyrae liberated from polyps of Aurelia aurita using settling plates in Tokyo Bay, Japan. Hydrobiologia 451: 247-258. 